\title{
Lymphoma no Hodgkin Burkitt’s lymphoma
}

\author{
Mirta D'Ambra* \\ Chairman of the World Academy of Medical Sciences, Ministry of Health, Argentina
}

Submission: October 01, 2018; Published: November 13, 2018

*Corresponding author: Mirta D’Ambra MD, Chairman of the World Academy of Medical Sciences in Argentina - Ministry of Health - Buenos Aires University- Buenos Aires, Argentina, South America

\begin{abstract}
Burkitt's lymphoma is a neoplasm that usually affects children and adolescents, in adults it is usually related to HIV. It is considered to be highly malignant due to its rapid replication capacity. If it is detected in early stages, it may have a high degree of remission with chemotherapy, but in cases of late detection, survival is very short. One of its complications is tumor lysis with renal failure and the physio pathological changes that this implies, for example, edema, such as the case presented.It is always important to remember that a good clinical history, a complete physical examination are the pillars of a medical assessment, associated with complementary laboratory tests, cabinet, biopsy, among others, can get to obtain quick and accurate diagnoses that allow treatment initiation timely in order to preserve and improve the quality of life of patients.

Keywords: Lymphomas; Neoplasm; Cabinet; Biopsy; Chemotherapy
\end{abstract}

\section{Introduction}

Lymphomas are a group of neoplastic diseases that originate in cells of the immune system, and that specifically affect the cells of the lymphopoieticsystem, which is responsible for producing the lymphocytes (Saénz, Andrade, Torres, 2015). These neoplasms can affect any of the lymphocytic cells, but most originate in B cells and to a lesser extent in T and NK cells. According to Pinilla et al, "lymphomas, the third most frequent malignant disease of the child, represent approximately $12 \%$ of new cases of cancer diagnosed in children under 15 years of age. These, around $40 \%$ are Burkitt's lymphomas or resemble them (Burkittlike). "Burkitt's lymphoma was described in 1958 by Dennis Burkitt, hence its name. According to his studies, this disease was a type of very aggressive lymphoma that frequently presented extranidal involvement in areas such as the bone marrow and the central nervous system (CNS)[1].

Burkitt's lymphoma belongs to the group of non-Hodking lymphomas of mature B cells and is highly malignant due to its great potential to duplicate cancer cells. "Tumor growth is rapid, and the most feared complication is the tumor lysis syndrome, which can trigger acute renal failure, which represents $2 \%$ of all lymphomas" (Hernández and Fuentes, 2016). Despite this, it can respond to treatment but in many cases its diagnosis is made in very advanced stages[2].

\section{Classification}

According to the literature reviewed this lymphoma is classified into three variants:

\section{Endemic}

Observed in children and adolescents with a peak between 4 and 7 years of age, usually from the tropical zone of Africa. An important feature is that most cases are related to the Epstein Barr virus, whichcauses infectious mononucleosis. This type occurs in bulky form in the jaw, orbit and other facial bones, in addition to the kidneys[3].

\section{Sporadic}

This variant does not have a defined geographic distribution but describes it as the American form, "it occurs in adults under 35 years of age, with a predominance in male sex of $4: 16$, with abdominal involvement and, frequently, infiltration. or $\mathrm{n}(30 \%)$, central nervous system (CNS) (15\%) and also kidney, testicular, overall, mammary or medulla"[4].

\section{Associated with Immunodeficiency}

"It appears mostly in people infected by the human immunodeficiency virus (HIV) and, unlike other neoplasms, it is characteristic that it occurs in patients with still preserved CD4 lymphocyte levels above 200/ $\mu$ l'.In adults, the disease can be voluminous and widespread, often with massive involvement of the liver, spleen and bone marrow. Frequently, there is compromise of the CNS at the time of diagnosis or in case of relapse of the lymphoma[5].Burkitt's lymphoma is the fastest growing human tumor, and the pathological anatomy reveals a high mitotic index, clonal proliferation of B lymphocytes and a "starry sky" pattern of benign macrophages 
that have encompassed apoptotic malignant lymphocytes. A characteristic genetic translocation is observed involving the C-myc gene of chromosome 8 and the immunoglobulin heavy chain of chromosome 14[6]. The disease is closely associated with infection by Epstein-Barr virus in endemic lymphoma; however, it has not been clarified if the Epstein-Barr virus plays an etiological role. Burkitt's lymphoma is frequent in patients with AIDS and may be a defining disease of said pathology.

\section{Conclusion}

Burkitt's lymphoma is a neoplasm that usually affects children and adolescents, in adults it is usually related to HIV. it is highly malignant due to its rapid replication capacity. if it is detected in early stages, it may have a high degree of remission with chemotherapy, but in cases of late detection, survival is very short. one of its complications is tumor lysis with renal failure and the physiopathological changes that this implies, for example, edema, such as the case presented. It is always important to remember that a good clinical history, a complete physical examination are the pillars of a medical assessment, associated with complementary laboratory tests, cabinet, biopsy, among others, can get to obtain quick and accurate diagnoses that allow treatment initiation timely in order to preserve and improve the quality of life patients

\section{Treatment}

\section{Intensive Chemotherapy}

Treatment should start quickly because the tumors grow at high speed. An intensive alternating scheme of cyclophosphamide, vincristine, doxorubicin, methotrexate, ifosfamide, etoposide, and cytarabine (codoxm/ivac) plus rituximab determines a cure rate $>90 \%$ in children and adults. Other regimens such as rituximab plus etoposide, prednisone, vincristine (oncovin), and doxorubicin (r-epoch) and rituximab plus cyclophosphamide, vincristine, doxorubicin (adriamycin) and dexamethasone (r-hyper cvad) are also commonly used successfully[7,8]. Meningeal prophylaxis is essential. With treatment, tumor lysis syndrome is common (see treatment of adverse effects of oncological treatment: tumor lysis syndrome), and patients should receive iv hydration, allopurinol often with rasburicase, alkalinization and strict electrolyte control $(\mathrm{k}$ and ca).

If the patient presents intestinal obstruction due to the tumor but the tumor is completely resected in the initial diagnostictherapeutic laparotomy, aggressive treatment is still indicated. In general, rescue treatment in case of therapeutic failures is not successful, which highlights the importance of a very aggressive initial treatment.

\section{References}

1. Beers HM, Porter SR, Jones VT, Kaplan LJ, Berkwits M (2007) Manual Merck. (11 ${ }^{\text {th }}$ edn.), Elsevier, Spain. pp. 1224-1226.

2. Harrison TR (2006) Principles of Internal Medicine. (16 ${ }^{\text {th }}$ edn). In: Part $\mathrm{V}$, (Eds.), Oncology and hematology. Clinical manifestations, treatment and prognosis of the different malignant lymphoid malignancies (in Spanish). Harrison online in Spanish, McGraw-Hill, Mexico.

3. Liu D, Shimonov J, Primanneni S, Lai Y, Ahmed T, et al. (2007) T 8, 14, 18: a 3-way chromosome translocation in two patients with Burkitt's lymphoma / leukemia. Mol Cancer 6: 35.

4. Cecil RLF, Russell FS, Lloyd H, Wyngaarden JB (2007) Treaty of internal medicine. (23 ${ }^{\text {rd }}$ edn). Saunders Elsevier; Philadelphia, USA. pp. 1411.

5. Horning SJ (2008) Hodgkin's lymphoma. In: Abeloff MD, Armitage JO, et al., (Eds.), Clinical Oncology. ( $4^{\text {th }}$ edn). Elsevier Churchill Livingstone, Philadelphia, USA. pp. 2274-2280.

6. Bacon CM, Du MQ Dogan A (2007) Mucosa-associated lymphoidtissue (MALT) lymphoma: a practical guide for pathologists. J Clin Pathol 60: 361-372.

7. Marcus R, Imrie K, Belch A, Cunningham D, Flores E, et al. (2005) CVP chemotherapy plus rituximab compared with CVP as first-line treatment for advanced follicular lymphoma. Blood 105: 1417-1423.

8. Olivieri A, Santini G, Patti C, Chisesi T, De Souza C, et al. (2005) Upfront high-dose sequential therapy (HDS) versus VACOP-B with or without HDS in aggressive non-Hodgkin's lymphoma: long-term results by the NHLCSG. Annals of Oncology 16: 1941-1948.

Your next submission with Juniper Publishers
will reach you the below assets
Quality Editorial service
Swift Peer Review
Reprints availability
E-prints Service
Manuscript Podcast for convenient understanding
Global attainment for your research
Manuscript accessibility in different formats
( Pdf, E-pub, Full Text, Audio)
Unceasing customer service
Track the below URL for one-step submission
tps://juniperpublishers.com/online-submission.php

